EMILIA SZYMCZAK

Uniwersytet im. Adama Mickiewicza

$w$ Poznaniu

\title{
SPOŁECZNE (RE)KONSTRUKCJE ZAWODU INŻYNIERA W KONTEKŚCIE ROSNĄCEGO UDZIAŁU KOBIET W TRADYCYJNIE MĘSKICH OBSZARACH ZAWODOWYCH
}

\begin{abstract}
Szymczak Emilia, Społeczne (re)konstrukcje zawodu inżyniera w kontekście rosnącego udziatu kobiet w tradycyjnie męskich obszarach zawodowych [Social (Re)construction Engineering Profession Analysis of this Phenomenon in the Context of the Growing Participation of Women in Traditionally Male Work Places]. Studia Edukacyjne nr 40, 2016, Poznań 2016, pp. 39-54. Adam Mickiewicz University Press. ISSN 1233-6688. DOI: 10.14746/se.2016.40.3
\end{abstract}

Nowadays, women more often want to pursue their professional aspirations in areas related to engineering. This is evidenced by statistical reports related to the growing participation of women in the polytechnic studies, as well as a growing proportion of young women working as engineer. It is inseparably connected with the contemporary changes and discoveries in technology, thanks to which the society - the remaining phase of permanent development - stands in the need for a greater number of specialists and workers in order to meet increasing, as well as constantly changing needs of social, economic and market conditions.

This article is a (re)construction of professional functioning of women in engineering with special emphasis on factors which may provide an incentive to undertake this type of work; analysis of the same professional environment in the context of the problem of social inequality, as well as the phenomenon of masculinization of women in engineering.

Key words: (re)contruction, women, engineering, masculinity, inequality, work

Niniejszy artykuł podejmuje kwestię jednego ze współczesnych zjawisk społecznych, jakim jest rosnący udział kobiet na studiach inżynierskich i technicznych. Cel prezentowanych rozważań stanowi próba odpowiedzi 
na pytanie, jak bardzo zmienił się współcześnie wizerunek inżyniera i co sprawia, że zawód ten jest coraz bardziej popularny wśród młodych kobiet, które podejmując decyzję o kształceniu na studiach wyższych coraz częściej wybierają politechniki.

Potwierdzeniem analizowanego trendu są obecne statystyki, z których wynika, że:

Od momentu rozpoczęcia akcji „Dziewczyny na politechniki!” w 2008 roku (a pilotażowo w roku 2007) nastąpił systematyczny wzrost liczby studentów w uczelniach technicznych. Od startu programu do roku akademickiego 2014/15 liczba studiujących na uczelniach technicznych zwiększyła się o 4811 osób przy ogólnym, gwałtownym spadku liczby studentów w Polsce'1.

Biorąc pod uwagę sukcesywnie pogłębiający się niż demograficzny i rokroczny - od roku $2005^{2}$ - spadek liczby studentów w Polsce, mamy do czynienia z rosnącym udziałem kobiet w kształceniu wyższym. Co ciekawe, dotyczy on także kierunków ścisłych i technicznych (przy jednoczesnym spadku liczby kształcących się na politechnikach mężczyzn). Jak donosi Raport Kobiety na politechnikach z 2016 roku.

W sumie do dziś liczba studentów na politechnikach w porównaniu z rokiem akademickim 2007/08 wzrosła o prawie 5 tysięcy (z 301042 do 305853 [osób - E.S.] $\mathrm{w}$ roku akademickim 2014/15). W tym czasie, od początku prowadzenia akcji „Dziewczyny na politechniki!", liczba dziewczyn na publicznych uczelniach technicznych jest większa (o 13999 [osób - E.S.]) niż w roku startu programu. Liczba mężczyzn spadła, w porównaniu z rokiem bazowym, o ponad 20 tysięcy33.

W prezentowanym tekście dokonam syntetycznej charakterystyki współczesnych przemian i tendencji w tym zakresie, jak również próby rekonstrukcji zawodu inżyniera $\mathrm{w}$ świetle mających miejsce przemian społecznych, politycznych i edukacyjnych.

Na początku należy wyjaśnić definicję pojęcia inżynieria, jak również to, kogo w istocie określa się mianem inżyniera. Według Słownika języka polskiego, inżynieria jest to „nauka wykonywania robót inżynierskich, umiejętność projektowania i wznoszenia różnych rodzajów budowli" 4 . Pojęcie to pochodzi od francuskiego słowa ingénierie, które wraz z pojęciem inżynier (ingén-

1 Kobiety na politechnikach 2016. Raport, Fundacja Edukacyjna Perspektywy, Marzec 2016, s. 2, źródło: http://dziewczynynapolitechniki.pl/2015/images/dla-mediow/raport-kobietynapolitechnikach-2016.pdf, [dostęp: 15.10.2016].

2 Szkolnictwo wyższe w Polsce, Raport MNiSW 2013, s. 18, źródło: https://www. nauka.gov.pl/g2/oryginal/2013_07/0695136d37bd577c8ab03acc5c59a1f6.pdf, [15.11.2016].

${ }^{3}$ Kobiety na politechnikach 2016. Raport, s. 4.

${ }^{4}$ M. Szymczak, Stownik jezzyka polskiego, t. 1, Warszawa 1978, s. 806. 
ieur) ma swoje źródło w słowie engigneor, oznaczającym konstruktora machin wojennych ${ }^{5}$. Jak można na podstawie tego wnioskować, inżynieria w jej pierwotnym rozumieniu - była poniekąd związana z działalnością stricte konstrukcyjną, mającą swoje urzeczywistnienie $\mathrm{w}$ dziedzinach związanych z tematem wojskowości i obronności.

Innego wyjaśnienia dostarcza Słownik pojęć wspótczesnych, który definiuje inżynierię jako „wykorzystywanie, surowców, metali i innych materiałów wytwarzanych z surowców [bądź] naturalnych źródeł energii”. W tym ujęciu stanowi ona

metodę naukową służącą konstruowaniu maszyn i innych urządzeń przeznaczonych do określonego celu. Ten cel jest zazwyczaj użytkowy - transport, komunikacja, zaopatrzenie $\mathrm{w}$ wodę - lecz może też (np. budowa radioteleskopu) pomagać $\mathrm{w}$ realizacji celów nauk przyrodniczych, tzn. służy poznaniu świata fizycznego. Właśnie stosowanie metod naukowych stanowi o przewadze inżynierii (mogącej obejmować także ręczną wytwórczość) nad tradycyjnym rzemiosłem i jest związane z techniką, której ważny dział w istocie stanowi

Inżynier rozumiany jest z kolei jako „specjalista mający wyższe wykształcenie w określonej dziedzinie wiedzy technicznej”7 lub jako „człowiek twórczego umysłu, wynalazca, konstruktor"8. Słownik języka polskiego pod redakcją W. Doroszewskiego zawiera natomiast zapis wyjaśniający, iż inżynier to "osoba mająca wyższe wykształcenie techniczne”. Jest to także "tytuł nadawany absolwentom wyższych uczelni technicznych"9.

Tytuł inżyniera niejednokrotnie kojarzony jest głównie z męską częścią społeczeństwa. Potwierdzeniem tego może być fakt, iż dokonując wstępnego przeglądu wybitnych polskich inżynierów i konstruktorów światowego formatu, szybko okazuje się, że wśród adresatów tego miana znajdują się głównie mężczyźni. Poszukując informacji na temat wybitnych Polakówinżynierów i konstruktorów, na myśl przychodzą takie nazwiska, jak np. Gabriel Narutowicz - inżynier, hydrotechnik, pierwszy prezydent Rzeczypospolitej, a zarazem pionier w zakresie wykorzystywania energii wodnej projektował i tworzył, a także nadzorował proces powstawania szeregu elektrowni wodnych w Europie Zachodniej10, Jacek Rafał Karpiński - inży-

${ }^{5}$ A. Bańkowski, Etymologiczny stownik języka polskiego, Warszawa 2000, s. 558-559.

${ }_{6}^{6}$ Stownik pojęć wspótczesnych, red. A. Bullock, O. Stallybrass, S. Trombley, B. Eadie, Katowice 1999 , s. 241.

${ }^{7}$ M. Szymczak, Stownik języka polskiego, s. 806.

8 A. Bańkowski, Etymologiczny stownik jezzyka polskiego, s. 558-559.

9 Stownik języka polskiego PWN, hasło: Inżynier, źródło: http://sjp.pwn.pl/szukaj/ in\%C5\%BCynier.html, [dostęp: 15.09.2016].

10 B. Orłowski, Gabriel Narutowicz - inżynier, Wiedza i Życie, 2007, 12, s. 24. 
nier, elektronik i informatyk, twórca minikomputera K-20211, Mieczysław Grzegorz Bekker - konstruktor pojazdu księżycowego LRV (Lunar Roving Vehicle)12, Stefan Feliks Manczarski - radioelektryk i geofizyk; stworzył pierwszy polski odbiornik radiofoniczny lampowy - telewizor13, czy Ernest Malinowski - inżynier, którego dziełem życia było stworzenie najwyżej położonej na świecie linii kolejowej znajdującej się w peruwiańskich Andach ${ }^{14}$. To jedynie przykłady osób, które należą do grupy wybitnych inżynierów i konstruktorów (o zasługach wykraczających niejednokrotnie poza granice naszego kraju), tworząc - przynajmniej w tym zestawieniu - bezsprzecznie męskie grono wybitnych i zasłużonych Polaków. Nie chcąc popełnić błędu generalizacji i mając świadomość istnienia jednostkowych przykładów kobiet odnoszących sukcesy $\mathrm{w}$ dziedzinach ścisłych (jak np. powszechnie znana Maria Skłodowska-Curie $\left.{ }^{15}\right)$, warto zwrócić uwagę, co nie ulega wątpliwości, iż w tym obszarze zawodowym występowała, niemalże od zawsze, supremacja męskiej części społeczeństwa.

Przyczyn takiego stanu rzeczy upatrywać można w tradycyjnej socjalizacji i podziale ról społecznych na tradycyjnie męskie i tradycyjnie kobiece ${ }^{16}$, jak również $\mathrm{w}$ tradycyjnym podziale pracy ${ }^{17}$, zgodnie z którym to mężczy-

11 Stynni Polacy w przeszłości, źródło: http://www.polskinetwork.org/strona,duma,110, slynni-polacy-w-przeszlosci.html, [dostęp: 15.09.2016].

12 Tamże.

${ }^{13} \mathrm{H}$. Berezowski, Stefan Manczarski - odbiorniki radiowe, źródło: http://telemuzeum. uke.gov.pl/telehistorie/4-telehistorie/telehistorie/78-stefan-manczarski-odbiorniki-

radiowe.html, [dostęp; 15.09.2016].

${ }^{14}$ S.M. Brzozowski, Ernest Malinowski - biografia, Internetowy Polski Słownik Biograficzny, źródło: http://www.ipsb.nina.gov.pl/a/biografia/ernest-malinowski, [dostęp: 15.09.2016].

15 W. Bulski, M. Sobieszczak-Marciniak, Maria Skłodowska-Curie - twórczyni Instytutu Radowego w Warszawie, Inżynier i Fizyk Medyczny, 2015, 4, 5, s. 301-304.

16 Socjalizację, w tym ujęciu, rozumieć można jako „kształtowanie w jednostce - na podstawie uogólnienia doświadczeń $\mathrm{w}$ środowisku społecznym i przekazywania $\mathrm{w}$ toku procesów komunikacji społecznej - określonych, zdeterminowanych społecznie i kulturowo, wewnętrznych regulatorów czynności i zachowań wraz ze schematami czynności, a także wzorów i reguł poznawczego ujmowania, opracowywania i interpretowania doświadczenia indywidualnego oraz jego emocjonalnego przeżywania i wartościowania": M. Tyszkowa, Badania nad uspołecznieniem i osobowościa dzieci jedynych i mających rodzeństwo, [w:] Rozwój dziecka w rodzinie i poza rodzina, red. M. Tyszkowa, Poznań 1985, s. 13.

17 Odwołując się teorii Pierre'a Bourdieu, można wyróżnić trzy komponenty genezy płciowej segregacji, wyrażające się m.in. w przekonaniach społecznych dotyczących pracy kobiet, która winna być skorelowana ze specyfiką działań w przestrzeni domowej oraz stanowić ich przedłużenie (odpowiednie dla kobiet dziedziny zawodowe winny być związane z nauczaniem, opieką lub sektorem usług). Kolejny kontekst wyznacza społeczne przekonanie o męskiej dominacji i słuszności pełnienia przez nich ważnych, prestiżowych zawodów. Ostatni komponent dotyczy przekonania, iż to mężczyzna jest pierwotnie predysponowany do obsługi maszyn i urządzeń technicznych. Miało to swoje odzwierciedlenie w edukacji wyższej 
zna w sposób szczególny predysponowany był do pełnienia prestiżowych i uznawanych społecznie ról publicznych i zawodowych, natomiast kobiety wypełniały szereg powinności związanych ze środowiskiem domowym i opieką nad dziećmi bądź następnie trudniły się pracą związaną z sektorem opieki, nauczania oraz usług18. Przyczynił się do tego dominujący przez długie lata paradygmat esencjalistyczny, zgodnie z którym różnice pomiędzy kobietami i mężczyznami są uwarunkowane biologicznie i w związku z tym skutecznie sytuują i dookreślają miejsce obu grup w społeczeństwie ${ }^{19}$, stanowiąc tym samym (cytując Z. Melosika) „logiczną konsekwencję różnic biologicznych" 20. Różnice te, determinujące (a niekiedy i całkowicie blokujące) wybory edukacyjne, a następnie zawodowe kobiet i mężczyzn, przez lata wzmacniane były też przez przekazywane z pokolenia na pokolenie wartości patriarchalne ${ }^{21} \mathrm{i}$ - będące ich konsekwencją - długo utrzymujące się szeroko pojęte tendencje naturalistyczne 22 oraz zinternalizowane społecznie schematy dotyczące kobiecości i męskości w myśl założeń konstruktywistycznych ${ }^{23}$.

Dysproporcje w liczbie uczących się na poziomie edukacji wyższej kobiet i mężczyzn, w szczególności na kierunkach ścisłych i technicznych, wynikały także - a niekiedy i przede wszystkim - z ograniczeń uniemożliwiających kształcenie uniwersyteckie kobiet - czy to w postaci całkowitego zakazu ${ }^{24}$, czy też $\mathrm{w}$ formie ustanowionego przez uczelnie numerus clausus 25 .

kobiet i przez długie lata determinowało wybory edukacyjne żeńskiej części społeczeństwa: P. Bourdieu, Męska dominacja, Warszawa 2004, s. 112.

18 J.S. Mcllwee, J.G. Robinson, Women in engineering. Gender, Power and Workplace culture, New York 1992, s. 11.

${ }^{19}$ A. Gromkowska-Melosik, Pat socjalizacyjny? Kontrowersje wokót społecznych konstrukcji kobiecości i męskości, [w:] Wychowanie. Pojęcia. Procesy. Konteksty, t. 5, red. M. Dudzikowa, M. Czerepaniak-Walczak, Gdańsk 2010, s. 185.

${ }^{20}$ Z. Melosik, Tożsamość, płeć i różnica w perspektywie ponowoczesnej, [w:] Męskość - kobiecość w perspektywie indywidualnej i kulturowej, red. J. Miluska, P. Boski, Warszawa 1999, s. 173.

${ }^{21}$ A. Gromkowska-Melosik, Edukacja i (nie)równość społeczna kobiet. Studium dynamiki dostępu, Kraków 2011, s. 214.

22 E. Badinter, Konflikt: Kobieta i matka, przekł. J. Jedliński, Warszawa 2013, s. XII.

23 E. Kaschak, Nowa psychologia kobiety. Podejście feministyczne, Gdańsk 2001, s. 187.

${ }^{24}$ Jednym z pierwszych krajów, który umożliwił kobietom studiowanie na uczelniach wyższych była Szwajcaria. Miało to miejsce w latach 40. XIX wieku; D. Pankowska, Wychowanie a role ptciowe, Gdańsk 2005, s. 116.

25 Przykładem może być Akademia Górnicza, gdzie w październiku 1922 roku ustanowiono numerus clausus w liczbie ośmiu kobiet przyjmowanych na pierwszy rok. Przyczyną podjęcia takiej decyzji była chęć uniknięcia i zminimalizowania rywalizacji pomiędzy kobietami i mężczyznami; A. Chadaj, O pierwszej kobiecie z dyplomem magistra inżyniera górnika, Górnictwo i Geoinżynieria, 2009, 3, s. 35-36. 
Ta niekorzystna sytuacja kobiet zaczęła zmieniać się dopiero pod koniec XIX wieku wraz z obejmującymi świat kolejnymi falami ruchów emancypacyjnych feministek ${ }^{26}$ i zapoczątkowującą je działalnością sufrażystek ${ }^{27}$. Wpłynęła na to również popularyzacja kształcenia i upowszechnienie szkół różnego szczebla, również na poziomie edukacji wyższej. W konsekwencji, dziś trudno już mówić (przynajmniej w krajach wysokorozwiniętych) o radykalnych i rażących nierównościach $\mathrm{w}$ dostępie do edukacji (w Polsce obowiązek równego traktowania wszystkich obywateli gwarantuje zapis w Konstytucji ${ }^{28}$ ). Okazuje się jednak, iż pomimo wzrostu aspiracji ${ }^{29} \mathrm{i}$ w konsekwencji wzrostu aktywności zawodowej kobiet (ma to swoje odzwierciedlenie w statystykach uczelni wyższych, gdzie kobiety stanowią większość studiujących w Polsce osób - w roku akademickim 2014/2015 stanowiły $58,1 \%$ wszystkich studiujących ${ }^{30}$ ) w dalszym ciągu jest ich mniej na uczelniach ścisłych i technicznych aniżeli mężczyzn (w roku akademickim 2014/2015 liczba kobiet wobec ogólnej liczby studentów uczelni technicznych w Polsce wynosiła $37 \%{ }^{31}$ ).

Przewaga mężczyzn $\mathrm{w}$ dziedzinie inżynierii wynika przede wszystkim $\mathrm{z}$ dalej funkcjonujących $\mathrm{w}$ społeczeństwie stereotypów ${ }^{32}$ i zinternalizowanych tradycyjnych przekonań33, które niekiedy sprawiają, iż kobiety i mężczyźni w dalszym ciągu czują się predysponowani do pełnienia innych, komplementarnych względem siebie ról społecznych i zawodowych. Jednak, czego potwierdzeniem są aktualne wyniki badań, tendencje te stopniowo ulegają zmianie i z roku na rok kobiety coraz częściej otwierają się na dziedziny należące do grupy STEM (Science, Technology, Engineering i Mathematics) i chcą spróbować swoich sil w nietradycyjnych dla nich zawodach.

${ }^{26}$ E. Gontarczyk, Kobiecość i męskość jako kategorie społeczno-kulturowe w studiach feministycznych. Perspektywa socjologiczno-pedagogiczna, Poznań 1995, s. 8, 83.

27 E. Malinowska, Konflikt ptci jako konflikt społeczny. Od „kwestii kobiecej” do problemu: demokracja bez egalitaryzmu? [w:] Męskość i kobiecość. Czy walka ptci? red. I. Machaj, R. Suchocka, Poznań 2009, s. 46-55.

28 Świadczy o tym następujący zapis pochodzący z Konstytucji Rzeczypospolitej Polskiej z 2 kwietnia 1997 roku: „Wszyscy są wobec prawa równi. Wszyscy mają prawo do równego traktowania przez władze publiczne", Konstytucja Rzeczypospolitej Polskiej z 2 kwietnia 1997 r., DzU nr 78 z 1997, poz. 483, art. 32, ust. 1.

${ }^{29}$ M. Holmes, What is Gender? Sociological Approaches, London 2007, s. 6.

${ }^{30}$ Kobiety na politechnikach 2016. Raport, s. 2.

31 Tamże, s. 5.

32 A. Gromkowska, Kobiecość w kulturze globalnej. Rekonstrukcje i reprezentacje, Poznań 2002, s. $42-53$.

33 Potencjat Kobiet dla Branży Technologicznej, Raport Badawczy 2015, s. 7, źródło: http:/ / potencjalkobiet.pl/pdf/RAPORT-Potencjal-kobiet-dla-branzy-technologicznej.pdf, [dostęp: 15.11. 2016]. 
Niejednokrotnie okazuję się, że odnoszą w nich sukcesy, czego przykładem może być Olga Malinkiewicz - polska fizyk, która zasłynęła w 2014 roku wynalezieniem alternatywnego, i zarazem innowacyjnego, sposobu czerpania energii słonecznej z wykorzystaniem perowskitów, które mogą być zastosowane ("drukowane") - dzięki opracowanej przez nią metodzie - na dowolnym podłożu34. Obecnie, jako współwłaścicielka spółki „Saule Technologies", zajmuje się komercjalizacją wynalazku, który spotkał się z bardzo pozytywnym odbiorem ze strony różnorodnych branż i gałęzi przemysłu w Polsce i na świecie - w szczególności na rynku energetycznym i w branży elektronicznej (oraz wzbudził zainteresowanie polskiej armii) ${ }^{35}$. Kolejnym przykładem kobiety odnoszącej sukcesy w nietradycyjnie kobiecym zawodzie jest pani kapitan Katarzyna Mazurek - kobieta, która w 2016 roku objęła dowodzenie transportowo-minowym okrętem Marynarki Wojennej ORP Lublin ${ }^{36}$. Co prawda, praca wykonywana przez panią kapitan nie jest bezpośrednio związana z dziedzinami technicznymi, jednak sama obecność kobiety na wysokim stanowisku $\mathrm{w}$ takim zawodzie może stanowić swoiste potwierdzenie pewnego rodzaju postępującej rewolucji społecznej i kulturowej.

Analizując rosnący udział kobiet na politechnikach, pojawia się pytanie, co takiego składnia kobiety do inwestowania w analizowany obszar zawodowy. Okazuje się, iż jednym z fundamentalnych czynników, który skutecznie zachęca żeńską część społeczeństwa do podejmowania studiów na kierunkach ścisłych i technicznych, są indywidualne zainteresowania kobiet. Podjęcie studiów inżynierskich i technicznych jest $\mathrm{w}$ tym ujęciu naturalną konsekwencją posiadanych pasji, umiejętności i predyspozycji oraz stanowi swoiste następstwo silnej motywacji wewnętrznej do studiowania takich kierunków ${ }^{37}$. Jeżeli dana dziewczyna od zawsze interesowała się naukami ścisłymi, które niezmiennie dawały jej satysfakcję, odczuwała radość z po-

34 O. Malinkiewicz i in., Perovskite solar cells employing organic charge-transport layers, Nature Photonics, 2014, 8, s. 128-132.

35 Saule Technologies przedstawiła pierwszy modut fotowoltaiczny wykonany z perowskitu, Centrum Informacji o Rynku Energetycznym, źródło: http://www.cire.pl/item,125862,1,0,0,0,0,0, saule-technologies-przedstawila-pierwszy-modul-fotowoltaiczny-wykonany-z-perowskitu.

html, [dostęp: 15.11.2016].

36 Przełomowy moment w historii polskiej armii: kobieta będzie dowodzić okrętem Marynarki Wojennej, źródło: http://m.tokfm.pl/Tokfm/7,110218,21040323,przelomowy-moment-w-historiipolskiej-armii-po-raz-pierwszykobieta.html, [dostęp: 15.11.2016].

37 N.A. Fouad i in., Stemming The Tide: Why Women Leave Engineering, Milwaukee 2012, s. 13, źródło: http://energy.gov/sites/prod/files/NSF_Stemming\%20the\%20Tide\%20Why\% 20Women\%20Leave\%20Engineering.pdf, [dostęp: 15.01.2016]; N. Leong i in., Gender and Racial Diversity in the Structural Engineering Profession, s. 7, źródło: http://static1.squarespace. com/static/55cba7dbe4b07ca3d73c39af/t/55ce4e24e4b06c2348a5dab6/1439583780768/Gender DiversityDraft_FINAL_Rev_v1.pd, [dostęp: 15.11.2016]. 
dejmowania takich aktywności i odnosiła w tych obszarach kształcenia relatywnie mniejsze lub większe sukcesy, podjęcie decyzji o kształceniu na studiach technicznych pozostaje tylko kwestią czasu.

O ile powyższy przykład wydaje się być idealnym i wymarzonym wariantem ścieżki edukacyjnej i zawodowej, winno się zwrócić uwagę na kolejny, znaczący czynnik determinujący i wpływający na wybory edukacyjne kobiet przed podjęciem studiów. Jest nim udział osób trzecich. Okazuje się zazwyczaj, iż kobiety studiujące na uczelniach technicznych, częściej aniżeli mężczyźni, wśród przyczyn, które skłoniły je do wybrania takiej drogi edukacyjnej wymieniają wpływ czynników zewnętrznych, związanych z doradztwem ze strony osób trzecich - najczęściej rodziny, przyjaciół, innych zaufanych osób lub mentorów, którzy skutecznie zachęcili je do wykorzystania i spożytkowania posiadanej wiedzy oraz umiejętności właśnie w kierunkach inżynierskich i technicznych ${ }^{38}$. W tym miejscu można przywołać raport pt. „Potencjał kobiet dla branży technologicznej”, opublikowany w 2015 roku przez Fundację Edukacyjną Perspektywy oraz Siemens Sp. z o.o. ${ }^{39}$. Wynika z niego, iż wspomniane już odpowiednie wzorce społeczne, kontakt z kobietami, które przeszły podobną drogę zawodową i osiągają w praktykowanym zawodzie sukcesy, jak również szeroko pojęty wpływ rówieśników czy wychowawców i nauczycieli może niejednokrotnie stanowić znaczący motywator ośmielający i zachęcający kobiety do inwestowania w kierunki ścisłe i techniczne ${ }^{40}$, a przy okazji zmniejszać poczucie lęku przed wybraniem nietradycyjnie kobiecej, a zarazem trudnej i wymagającej, ścieżki zawodowej oraz pozwolić na wyższą i bardziej obiektywną ocenę posiadanych umiejętności i predyspozycji ${ }^{41}$.

38 Tamże, s. 8.

39 Raport zawiera kompleksową analizę uwarunkowań dotyczących wyborów edukacyjnych i zawodowych kobiet w branży technologicznej. Badaniom poddano 2000 maturzystek (1500 maturzystek z roku 2015, których odpowiedzi porównano z 500-osobową grupą maturzystek wybierających studia techniczne z 15 miast w Polsce), prawie 200 studentek uczelni technicznych, jak również 15 firm technologicznych. Autorki raportu to: dr Monika Ksieniewicz, dr Maria Pawłowska, dr Bianka Siwińska (kierownik), Monika Banach, Berenika Dąbrowska-Siuchno, Anna Domińska, Greta Gober, Joanna Lisiecka, Agata Młodawska, Marlena Piotrowska, Wojciech Terlikowski, Barłłomiej Więckowski, Katarzyna Zwolak; Potencjat Kobiet dla Branży Technologicznej.

40 Potwierdzają to statystyki z Wielkiej Brytanii, z których dowiadujemy się, iż dla 91\% z 300 badanych kobiet-inżynierów wpływ nauczyciela stanowił istotny przyczynek do podjęcia wybranej drogi zawodowej; Britain's got talented female engineers. Successful women in engineering: A careers research study, Atkins Limited 2013, s. 6, źródło: http://www.raeng.org.uk/ publications/other/britains-got-talented-female-engineers, [dostęp: 15.11. 2016].

41 Potencjat Kobiet dla Branży Technologicznej, s. 28-29, 42-43. 
Niniejszy raport wymienia szereg czynników, które mają decydujący wpływ na podjęcie przez młode kobiety studiów w dziedzinie inżynierii. Wśród nich możemy wymienić takie argumenty, jak ${ }^{42}$ : wysoki poziom kształcenia (według 58\% respondentek), większe szanse na uzyskanie pracy po ukończeniu szkoły wyższej (zgodnie z odpowiedziami 57\% maturzystek) oraz możliwość doskonalenia i rozwijania indywidualnych zainteresowań w danej dziedzinie (zgodnie z odpowiedzią 43\% badanych młodych kobiet). Do czynników o mniejszym wpływie należy: miasto, w którym znajduje się uczelnia (odpowiedziało tak 31\% respondentek), relatywnie niskie koszty studiowania (według 22\% pytanych maturzystek), prestiż i renoma danej uczelni (według 21\% badanych kobiet), szanse na podjęcie stażu (zdaniem $22 \%$ respondentek), jak również możliwość wzięcia udziału w wymianie zagranicznej $\mathrm{w}$ ramach realizowanych studiów (zgodnie $\mathrm{z}$ odpowiedziami $18 \%$ młodych kobiet) ${ }^{43}$. Tylko dla 10\% badanych maturzystek kryterium wyboru danej uczelni, jako miejsca realizowanych studiów, była „łatwość studiowania" 44 .

Innym źródłem, które dostarcza informacji wyjaśniających, dlaczego kobiety decydują się realizować swoją ścieżkę edukacyjną, a następnie zawodową w dziedzinie inżynierii jest raport z 2013 roku pt. „Britain's got talented female engineers Successful women in engineering: A careers research study" [Utalentowane kobiety inżynier w Wielkiej Brytanii. Kobiety sukcesu w inżynierii: Studium badawcze karier]. Wynika z niego, iż do głównych przyczyn, które skłoniły kobiety do podjęcia studiów w dziedzinie inżynierii należą: większe możliwości w zakresie realizowania przyszłej kariery zawodowej - różnorodność obszarów oraz miejsc wykorzystania zdobytej w toku studiów wiedzy i umiejętności (na ten czynnik zwróciło uwagę 62\% z 300 pytanych kobiet) oraz uznanie obszaru zawodowego, jakim jest inżynieria za dobrą i korzystną drogę umożliwiającą wielotorowe i wielopoziomowe osiągnięcie kariery (odpowiedziało tak $56 \%$ badanych kobiet). Inwestowanie $\mathrm{w}$ ten obszar edukacyjny $\mathrm{i}$ zawodowy to ponadto, zgodnie $\mathrm{z}$ odpowiedziami udzielonymi przez respondentki, szansa na zdobycie miejsca $\mathrm{w}$ prestiżowej i cieszącej się dużym uznaniem społecznym uczelni (według 50\% respondentek) oraz na podjęcie dobrej pracy i w konsekwencji zdobycie satysfakcjonującej posady (odpowiedziało tak 49\% respondentek). Kolejnymi czynnikami wskazywanymi przez respondentki i związanymi $\mathrm{z}$ realizacją drogi edukacyjnej oraz zawodowej $\mathrm{w}$ dziedzinie inżynierii jest

\footnotetext{
42 Każda maturzystka mogła wybrać kilka zaproponowanych odpowiedzi.

43 Tamże, s. 19.

44 Tamże.
} 
możliwość realizacji i sprawdzania własnych umiejętności w odmiennej aniżeli typowo kobieca - roli zawodowej (zwróciło na to uwagę 45\% respondentek) oraz realne i uzasadnione perspektywy dobrej i satysfakcjonującej pensji (odpowiedziało tak 35\% kobiet). Również i ten raport dowodzi, iż niejednokrotnie - na co zwróciły uwagę respondentki - wybór takiej drogi edukacyjnej i zawodowej stanowi konsekwencję i swoisty efekt wpływu doradztwa i sugestii - ze strony spotkanych na swojej drodze nauczycieli bądź mentorów (odpowiedziało tak $27 \%$ respondentek). Pojawiały się także wypowiedzi, iż $\mathrm{w}$ momencie podejmowania decyzji dotyczącej edukacji wyższej na kierunkach technicznych, kobiety brały pod uwagę możliwość otrzymania dotacji po ukończeniu nauki (zgodnie z odpowiedziami 18\% respondentek). Z kolei, $17 \%$ pytanych kobiet sugerowało się możliwością pogodzenia przyszłej pracy zawodowej z życiem prywatnym. Nieznaczna część badanych kobiet przyznała, iż wybór takiej drogi to rezultat porad udzielanych ze strony szkolnego doradcy zawodowego (odpowiedziało tak również 17\%) ${ }^{45}$.

Podsumowując tę część rozważań, można przywołać wyniki badań pilotażowych przeprowadzonych przez Ireneusza Zawłockiego, Krzysztofa Niewiadomskiego i Ewę Nierobę (z Politechniki Częstochowskiej). Zgodnie z nimi do czynników wpływających na wybór studiów technicznych przez kobiety należą: przekonanie społecznie, że ukończenie uczelni z dwoma tytułami (m.in. tytułem zawodowym inżyniera) rozszerza zakres możliwości w kwestii znalezienia przyszłej pracy, co jest bardziej korzystne aniżeli ukończenie nauki $\mathrm{w}$ akademii bądź na uniwersytecie ${ }^{46}$. Potwierdzają to ubiegłoroczne maturzystki, które uważają, iż studia w zakresie inżynierii stanowią gwarancję osiągnięcia dobrej pracy (zgodnie z odpowiedziami $72 \%$ respondentek) ${ }^{47}$. Innymi czynnikami, które zdaniem studentek mogą stanowić skuteczną zachętę do podjęcia tego typu studiów jest: uznanie w oczach mężczyzn spowodowane studiowaniem tradycyjnie męskiego kierunku (odpowiedziało tak 38\% respondentek), chęć sprawdzenia samej siebie i szansa na skonfrontowanie posiadanych umiejętności (według $25 \%$ pytanych młodych kobiet), lepsza, możliwa do uzyskania, praca (zdaniem 20\% respondentek) oraz (jako ostatnie pod względem liczby udzielonych odpowiedzi) równe traktowanie zarówno kobiet, jak i mężczyzn ${ }^{48}$.

45 Britain's got talented female engineers, s. 17.

${ }^{46}$ I. Zawłocki, K. Niewiadomski, E. Nieroba, Czynniki wptywające na wybór studiów technicznych przez kobiety, Edukacja - Technika - Informatyka, 2010, 1, s. 151.

47 Potencjat Kobiet dla Branży Technologicznej, s. 20.

${ }^{48}$ I. Zawłocki, K. Niewiadomski, E. Nieroba, Czynniki wptywające na wybór studiów technicznych przez kobiety, s. 152. 
Powyższe przekonania $\mathrm{w}$ pewien sposób korespondują z ogólną wizją współczesnej inżynierii, która stanowi bezsprzecznie jeden $\mathrm{z}$ najbardziej pożądanych obecnie obszarów zawodowych. Przyczyną tego jest nieustanny rozwój technologiczny państw i regionów determinujący i odpowiadający za rosnące zapotrzebowanie na różnego rodzaju specjalistów ${ }^{49}$, jak i pracowników - w szczególności profesjonalizujących się w dziedzinach ścisłych i technicznych - a wszystko w celu zaspokojenia zwiększających się i zarazem nieustannie zmieniających się potrzeb ekonomicznych, społecznych i rynkowych ${ }^{50}$. W konsekwencji, kierunki ścisłe i techniczne stają się coraz bardziej popularne i wartościowe z punktu widzenia rozwoju gospodarczego i społecznego. W tym miejscu można przywołać postulaty organizacji National Academy of Engineers w Stanach Zjednoczonych, które stanowią potwierdzenie powyższych tendencji. Wśród nich w sposób szczególny akcentuje się racjonalność, użyteczność i potrzebę inwestowania w nauki związane $\mathrm{z}$ technologią $\mathrm{w}$ celu systematycznego zwiększenia się konkurencyjności partykularnych przestrzeni lokalnych, narodowych i ponadnarodowych w ramach światowego rynku gospodarczego ${ }^{51}$.

Biorąc pod uwagę fakt, iż sama obecność mężczyzn przestaje wystarczać, kolejnym krokiem pozwalającym na wdrażanie analizowanej polityki $\mathrm{w}$ życie jest zachęcanie kobiet do inwestowania w takie dziedziny kształcenia - doceniając przy tym ich potencjał i nieoceniony wpływ na społeczeństwo. Przykładem komunikatu społecznego, który w sposób szczególny uznaje wartość kobiet i pozytywnie wzmacnia ich rosnący udział w dziedzinach ścisłych i technicznych jest wypowiedź Bianki Siwińskiej z ramienia Fundacji Edukacyjnej Perspektywy:

Kobiety stanowią olbrzymi, niewykorzystany dotąd potencjał, który może nadać rozwojowi branży technologicznej impet i nową jakość. Ich zaangażowanie i unikalna perspektywa tworzą szansę na nowy sposób rozwiązywania problemów współczesności. Na budowanie kompetentnego społeczeństwa, które z zaawansowanych technologii będzie umiało korzystać mądrze i odpowiedzialnie ${ }^{52}$.

49 E. Croft, J. Pelletier, Diversity in Organizations - Why and How, "Innovation", September/ October 2012, s. 18, źródło: http:// wwest.mech.ubc.ca/files/2013/08/Innovation-September_ October-2012-article.pdf, [dostęp: 15.11.2016].

50 Science policies in the European Union. Promoting excellence through mainstreaming gender equality, A Report from the ETAN Expert Working Group on Women and Science, European Commission Research Directorate-General, Bruselas 2000, s. XI, źródło: ftp://ftp.cordis. europa.eu/pub/improving/docs/g_wo_etan_en_200101.pdf, [dostęp: 15.11.2016].

${ }^{51}$ N.A. Fouad i in., Stemming the Tide: Why Women Leave Engineering, s. 12.

52 Potencjat Kobiet dla Branży Technologicznej, s. 5. 
W odpowiedzi na te argumenty oraz wzmożone zainteresowanie potencjałem żeńskiej części społeczeństwa (który z powodzeniem może być wykorzystywany $w$ tych obszarach zawodowych), kobiety - co potwierdzają przywołane na początku artykułu dane statystyczne - coraz częściej wykazują chęć podejmowania studiów i spróbowania swoich sił w nietradycyjnych dla nich dyscyplinach ${ }^{53}$.

Owocem niniejszej polityki edukacyjnej jest zaawansowana i wielokierunkowa popularyzacja kierunków ścisłych i technicznych, której urzeczywistnienie stanowi szereg akcji społecznych mających na celu zachęcić przyszłych studentów do inwestowania w te kierunki i obszary. Przykładem takich działań może być podejmowana już po raz dziewiąty w Polsce akcja społeczna „Dziewczyny na politechniki”54, jak również organizowana w jej ramach akcja "Dziewczyny do ścisłych" oraz „Lean in STEM" (dosłownie: „Włącz się do obszarów z grupy STEM") 55 z ramienia Fundacji Edukacyjnej Perspektywy, które koordynuje wspomniana już B. Siwińska ${ }^{56}$. Biorąc pod uwagę organizacje ponadnarodowe, można wymienić takie akcje, jak np.: powstały z inicjatywy Komisji Europejskiej program: „Science: It's a Girl Thing!” (w polskiej wersji akcja nosi nazwę: "Nauki ścisłe są dla dziewczyn!") 57 czy belgijską organizację (o zasięgu międzynarodowym) "Greenlight for Girls” (dosłownie: „Zielone światło dla dziewcząt”), inicjującą m.in. tzw. g4g Day ${ }^{58}$. To jedynie przykłady działań i inicjatyw, które mają na celu zachęcić kobiety do podejmowania studiów, a następnie pracy w takich obszarach zawodowych. W istocie jest ich znacznie więcej. Tylko na stronie akcji „Science: It's a Girl Thing!” z ramienia Komisji Europejskiej znajdziemy linki do ponad 70 innych organizacji i instytucji zajmujących się omawianym zagadnieniem ${ }^{59}$. Wszystkie łączy jeden cel: maksymalne zaktywizowanie, wzmocnienie poczucia własnej wartości i posiadanych kompetencji, jak i - w

53 J. Evetts, Gender and Career in Science and Engineering, London 1996, s. 4.

${ }^{54}$ Dziewczyny na politechniki, źródło: http://dziewczynynapolitechniki.pl/2015/index. php?option=com_content\&view=article\&id=160:raport-qkobiety-na-politechnikach2016q\&catid=1:aktualnosci, [dostęp: 20.11.2016].

${ }^{55}$ Lean in STEM, źródło: http:/ / leaninstem.pl/o-programie, [dostęp: 15.10.2016].

${ }^{56}$ Kobiety na politechnikach, Raport, Fundacja Edukacyjna Perspektywy, Marzec 2015, s. 2, źródło: http://dziewczynynapolitechniki.pl/2015/pdfy/Raport_Kobiety_na_politechnikach _2015.pdf, [dostęp: 15.10.2016].

57 Commission launches “Science: it's a girl thing!" campaign, 2012, źródło: http:// europa.eu/rapid/press-release_MEMO-12-465_en.htm?locale=en, [dostęp:15.11.2016]. 2016].

${ }^{58}$ Greenlight for Girls, źródło: http://greenlightforgirls.org/our-story/, [dostęp: 15.10.

${ }^{59}$ Nauki ścisłe są dla dziewczyn, źródło: http:/ / science-girl-thing.eu/pl, [dostęp: 15.09.2016]. 
konsekwencji - skuteczne zmotywowanie kobiet do udziału i inwestowania w kierunki ścisłe i techniczne.

W tym miejscu można zwrócić uwagę również na to, iż omawianym tendencjom społecznym, kulturowym i edukacyjnym sprzyja współczesny wizerunek inżynierii, która $\mathrm{w}$ najaktualniejszej odsłonie nie jest już rozumiana jako zawód stricte konstrukcyjny, nieodłącznie powiązany z koniecznością wykorzystywania dużej siły i sprawności fizycznej. Okazuje się, że $\mathrm{w}$ dobie technologizacji inżynieria zostaje $\mathrm{w}$ pewnym stopniu oderwana od wyłącznie konstrukcyjnej i fizycznej pracy, przekształcając się niejednokrotnie $w$ zawód wymagający sprawnego posługiwania się specjalistycznymi programami i urządzeniami lub ich nadzoru. Jest też obszarem, który sukcesywnie rozszerza pole działania dla kadry zarządzającej i kierowniczej. Może to niejednokrotnie stanowić znaczące ułatwienie, realną zaletę i niewymierną wartość dla żeńskiej części społeczeństwa ${ }^{60}$.

Obszar zawodowy jakim jest inżynieria jawi się jako perspektywiczny i obiecujący na przyszłość, który - poprzez inwestowanie w niego - może stanowić wartościowe remedium i zarazem sposób na przezwyciężenie mających miejsce $\mathrm{w}$ wielu społeczeństwach trudności związanych $\mathrm{z}$ brakiem miejsc pracy czy szeroko rozumianym przekwalifikowaniem społeczeństwa. Daje on bowiem większe szanse na otrzymanie satysfakcjonującej, wysokopłatnej pracy i ogólnie rozumiany rozwój zawodowy. Równocześnie może stanowić realne źródło osobistej satysfakcji i poczucia bezpieczeństwa, wynikających między innymi ze świadomości, iż jest to $w$ dalszym ciągu prestiżowy, uznawany społecznie i wartościowany dodatnio obszar zawodowy ${ }^{61}$.

W latach siedemdziesiątych XX wieku w Stanach Zjednoczonych znana była piosenka Peggy Seeger „I'm Gonna Be an Engineer" 62, stanowiąca swoistą egzemplifikację pragnień i marzeń żeńskiej części społeczeństwa tego okresu, która niejednokrotnie dążyła do tego, by móc - tak jak mężczyźni realizować swoje aspiracje $w$ tradycyjnie męskim zawodzie, jakim jest $n p$. inżynieria. Dzisiaj decyzja o tym, czy owe marzenia zostaną spełnione czy nie zależy w dużej mierze od samych kobiet, ich wyborów edukacyjnych, posiadanej wiedzy, aspiracji i osobistych zainteresowań.

$\mathrm{Z}$ uwagi na to, obserwując współczesne przemiany społeczne i kulturowe, można zaryzykować stwierdzenie, iż jesteśmy świadkami postępującej

\footnotetext{
${ }^{60}$ J.S. McIlwee, J.G. Robinson, Women in engineering, s. 3.

61 Tamże, s. 31.

${ }^{62}$ I'm Gonna Be An Engineer, źródło: http://www.lyricsfreak.com/p/peggy+seeger/im+ gonna+be+an+engineer_20254409.html, [dostęp: 15.11.2016].
} 
rewolucji kulturowej. Czy jednak można mówić o pełnej rewolucji patrząc na dane statystyczne, z których jednoznacznie wynika, że kobiety na studiach inżynierskich i technicznych stanowią $\mathrm{w}$ dalszym ciągu mniejszość?63 $\mathrm{Z}$ pewnością nie do końca. $\mathrm{Z}$ drugiej jednak strony, czy poprawne byłoby całkowite rezygnowanie $z$ tego pojęcia, mając na uwadze fakt rzeczywistych przemian społecznych i kulturowych, które pozostają niejednokrotnie w opozycji do tradycyjnych, od wieków zakorzenionych w świadomości społecznej, wyborów i funkcji społecznych pełnionych przez obie grupy kobiety i mężczyzn? Propozycją terminu pozwalającego na zestawienie tychże przeciwstawnych faktów i zjawisk jest oksymoron, który można znaleźć w raporcie „Potencjał kobiet dla branży technologicznej” z 2015 roku, o nazwie: „pełzająca rewolucja” 64 . $Z$ jednej strony pojęcie to wyraża rewolucyjne, współczesne przezmiany społeczne, jednak akcentuje zarazem, iż postępują one zbyt wolno w stosunku do ogólnego zapotrzebowania społecznego ${ }^{65}$. Okazuje się zatem, że o ile można mówić o postępujących zmianach $\mathrm{w}$ inżynierii, gdzie $\mathrm{z}$ roku na rok pracuje i realizuje się coraz większa grupa kobiet, to z drugiej strony wydaje się, że konieczne jest, aby minęło sporo czasu, by móc mówić o pełnej równości pracujących w tym - póki co wciąż jeszcze zdominowanym przez mężczyzn - obszarze zawodowym.

\section{BIBLIOGRAFIA}

Badinter E., Konflikt: Kobieta i matka, przekł. J. Jedliński, Wydawnictwo Naukowe PWN, Warszawa 2013.

Bańkowski A., Etymologiczny stownik języka polskiego, Wydawnictwo Naukowe PWN, Warszawa 2000.

Berezowski H., Stefan Manczarski - odbiorniki radiowe, źródło: http://telemuzeum.uke. gov.pl/telehistorie/4-telehistorie/telehistorie/78-stefan-manczarski-odbiornikiradiowe.html, [dostęp: 15.09.2016].

Bourdieu P., Męska dominacja, Oficyna Naukowa, Warszawa 2004.

Britain's got talented female engineers Successful women in engineering: A careers research study, Atkins Limited 2013, źródło: http://www.raeng.org.uk/publications/other/ britains-got-talented-female-engineers, [dostęp: 15.11.2016].

Brzozowski S.M., Ernest Malinowski - biografia, Internetowy Polski Słownik Biograficzny, źródło: http://www.ipsb.nina.gov.pl/a/biografia/ernest-malinowski, [dostęp: 15.09.2016].

${ }^{63}$ J.E. Mills i in., Challenging Knowledge, Sex and Power: Gender, Work and Engineering, New York 2014, s. 37.

${ }^{64}$ Potencjat kobiet dla branży technologicznej, s. 76.

65 Tamże. 
Bulski W., Sobieszczak-Marciniak M., Maria Skłodowska-Curie - twórczyni Instytutu Radowego w Warszawie, Inżynier i Fizyk Medyczny, 2015, 4, 5.

Chadaj A., O pierwszej kobiecie z dyplomem magistra inżyniera górnika, Górnictwo i Geoinżynieria, 2009, 3.

Commission launches "Science: it's a girl thing!" campaign, 2012, źródło: http:// europa.eu/rapid/press-release_MEMO-12-465_en.htm?locale=en, [dostęp: 15.11 . 2016].

Croft E., Pelletier J., Diversity in Organizations - Why and How, "Innovation”, September/October 2012, s. 18, źródło: http://wwest.mech.ubc.ca/files/2013/08/Inno vation-September_October-2012-article.pdf, [dostęp: 15.11.2016].

Dziewczyny na politechniki, źródło: http://dziewczynynapolitechniki.pl/2015/index. php?option=com_content\&view=article\&id=160:raport-qkobiety-na-politechni kach-2016q\&catid=1:aktualnosci, [dostęp: 20.11.2016].

Evetts J., Gender and Career in Science and Engineering, Taylor \& Francis, London 1996.

Fouad N.A., Singh R., Fitzpatrick M.E., Liu J.P., Stemming the Tide: Why Women Leave Engineering, University of Wisconsin - Milwaukee, 2012, s. 13, źródło: http:// energy.gov/sites/prod/files/NSF_Stemming\%20the \%20Tide \%20Why\%20Women \%20Leave\%20Engineering.pdf, [dostęp: 15.01.2016]

Gontarczyk E., Kobiecość i męskość jako kategorie społeczno-kulturowe w studiach feministycznych. Perspektywa socjologiczno-pedagogiczna, Wydawnictwo Eruditus, Poznań 1995.

Greenlight for Girls, źródło: http:/ / greenlightforgirls.org/our-story/ [dostęp: 15.10.2016].

Gromkowska A., Kobiecość w kulturze globalnej. Rekonstrukcje i reprezentacje, Wydawnictwo Wolumin, Poznań 2002.

Gromkowska-Melosik A., Pat socjalizacyjny? Kontrowersje wokół społecznych konstrukcji kobiecości i męskości, [w:] Wychowanie. Pojęcia. Procesy. Konteksty, red. M. Dudzikowa, M. Czerepaniak-Walczak, t. 5, Gdańskie Wydawnictwo Psychologiczne, Gdańsk 2010.

Gromkowska-Melosik A., Edukacja i (nie)równość społeczna kobiet. Studium dynamiki dostępu, Oficyna Wydawnicza Impuls, Kraków 2011.

Holmes M., What is Gender? Sociological Approaches, Sage Publications, London 2007.

I'm Gonna Be An Engineer, źródło: http://www.lyricsfreak.com/p/peggy+seeger/ im+gonna+be+an+engineer_20254409.html, [dostęp: 15.11.2016].

Kaschak E., Nowa psychologia kobiety. Podejście feministyczne, Gdańskie Wydawnictwo Psychologiczne, Gdańsk 2001.

Kobiety na politechnikach, Raport. Fundacja Edukacyjna Perspektywy, Marzec 2015, s. 2, źródło: http://dziewczynynapolitechniki.pl/2015/pdfy/Raport_Kobiety_na_politech nikach_2015.pdf, [dostęp: 15.10.2016].

Kobiety na politechnikach 2016. Raport, Fundacja Edukacyjna Perspektywy, Marzec 2016, źródło: http:/ / dziewczynynapolitechniki.pl/2015/images/dla-mediow/raportkobie ty-napolitechnikach-2016.pdf, [dostęp: 15.10.2016].

Konstytucja Rzeczypospolitej Polskiej z 2 kwietnia 1997 r., DzU nr 78 z 1997, poz. 483, art. 32, ust. 1.

Lean in STEM, źródło: http:/ / leaninstem.pl/o-programie, [dostęp: 15.10.2016].

Leong N., Liel A.B., Mitrani-Reiser J., Guglielmo E., Friis D., Lumbard D., Oliveira R., Pekelnicky R., Gender and Racial Diversity in the Structural Engineering Profession, źródło: http://static1.squarespace.com/static/55cba7dbe4b07ca3d73c39af/t/55ce 4e24e4b06c2348a5dab6/1439583780768/GenderDiversityDraft_FINAL_Rev_v1.pd, [dostęp: 15.11.2016]. 
Malinkiewicz O. i in., Perovskite solar cells employing organic charge-transport layers, Nature Photonics, 2014, 8.

Malinowska E., Konflikt ptci jako konflikt społeczny. Od "kwestii kobiecej” do problemu: demokracja bez egalitaryzmu? [w:] Męskość i kobiecość. Czy walka ptci? red. I. Machaj, R. Suchocka, Wydawnictwo Wyższej Szkoły Nauk Humanistycznych i Dziennikarstwa, Poznań 2009.

McIlwee J.S., Robinson J.G., Women in engineering. Gender, Power and Workplace culture, State University of New York Press, New York 1992.

Melosik Z., Tożsamość, płeć i różnica w perspektywie ponowoczesnej, [w:] Męskość - kobiecość w perspektywie indywidualnej i kulturowej, red. J. Miluska, P. Boski, Polskie Towarzystwo Psychologiczne, Warszawa 1999.

Mills J.E., Franzway S., Gill J., Sharp R., Challenging Knowledge, Sex and Power: Gender, Work and Engineering, Routledge, New York 2014.

Nauki ścisłe sa dla dziewczyn, źródło: http:/ / science-girl-thing.eu/pl, [dostęp: 15.09.2016].

Orłowski B., Gabriel Narutowicz - inżynier, Wiedza i Życie, 2007, 12.

Pankowska D., Wychowanie a role ptciowe, Gdańskie Wydawnictwo Psychologiczne, Gdańsk 2005.

Potencjat Kobiet dla Branży Technologicznej, Raport Badawczy 2015, źródło: http:// potencjalkobiet.pl/pdf/RAPORT-Potencjal-kobiet-dla-branzy-technologicznej.pdf, [dostęp: 15.11.2016].

Przełomowy moment w historii polskiej armii: Kobieta będzie dowodzić okrętem Marynarki Wojennej, źródło: http://m.tokfm.pl/Tokfm/7,110218,21040323,przelomowy-momentw-historii-polskiej-armii-po-raz-pierwszykobieta.html, [dostęp: 15.11.2016].

Saule Technologies przedstawita pierwszy modut fotowoltaiczny wykonany z perowskitu, Centrum Informacji o Rynku Energetycznym, źródło: http://www.cire.pl/item,125862, 1,0,0,0,0,0,saule-technologies-przedstawila-pierwszy-modul-fotowoltaicznywykonany-z-perowskitu.html, [dostęp: 15.11.2016].

Science policies in the European Union. Promoting excellence through mainstreaming gender equality, A Report from the ETAN Expert Working Group on Women and Science, European Commission Research Directorate-General, Bruselas 2000, źródło: ftp://ftp.cordis.europa.eu/pub/improving/docs/g_wo_etan_en_200101.pdf, [dostęp: 15.11.2016].

Stownik języka polskiego PWN, hasło: Inżynier, źródło: http://sjp.pwn.pl/szukaj/in\%C5\% BCynier.html, [dostęp: 15.09.2016].

Stownik pojęć wspótczesnych, red. A. Bullock, O. Stallybrass, S. Trombley, B. Eadie, Wydawnictwo Książnica, Katowice 1999.

Stynni Polacy w przeszłości, źródło: http://www.polskinetwork.org/strona,duma, 110,slynni-polacy-w-przeszlosci.html, [dostęp: 15.09.2016].

Szkolnictwo wyższe w Polsce, Raport MNiSW 2013, źródło: https://www.nauka. gov.pl/g2/oryginal/2013_07/0695136d37bd577c8ab03acc5c59a1f6.pdf, [15.11.2016].

Szymczak M., Stownik języka polskiego, t. 1, Państwowe Wydawnictwo Naukowe, Warszawa 1978.

Tyszkowa M., Badania nad uspołecznieniem i osobowościa dzieci jedynych i majacych rodzeństwo, [w:] Rozwój dziecka w rodzinie i poza rodzina, red. M. Tyszkowa, Wydawnictwo Naukowe UAM, Poznań 1985.

Zawłocki I., Niewiadomski K., Nieroba E., Czynniki wpływające na wybór studiów technicznych przez kobiety, Edukacja - Technika - Informatyka, 2010, 1. 